\title{
Occupational risks for renal cancer in Sweden
}

\author{
J K MCLAUGHLIN, ${ }^{12}$ H S R MALKER, ${ }^{3}$ B J STONE, ${ }^{2}$ J A WEINER, ${ }^{3}$

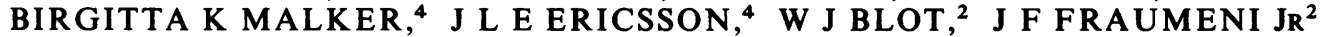 \\ From the Biostatistics Branch ${ }^{1}$ and Epidemiology and Biostatistics Program, Division of Cancer Etiology, ${ }^{2}$ \\ National Cancer Institute, Bethesda, Maryland 20892, USA, and National Board of Occupational Safety and \\ Health, ${ }^{3}$ Solna, S-171 84, and National Board of Health and Welfare, ${ }^{4}$ Stockholm, S-106 30, Sweden
}

\begin{abstract}
A systematic assessment was made of the occurrence of renal cancer among men by industrial and occupational classification using the Cancer-Environment Registry, which links cancer incidence (1961-79) and census data (1960) with industry and occupation for all employed individuals in Sweden. Data were analysed separately for cancers of the renal parenchyma and pelvis. Significantly increased risks for renal cell cancer were observed for several professional and white collar occupations, including physicians and others in the health care industry. By contrast, the risks for renal pelvis cancer tended to be higher among blue collar workers, especially in the machine industry. Deficits of both cancers occurred among farmers. The findings of the survey are considered as aetiological clues that may deserve further study, although some associations support observations in other countries.
\end{abstract}

Little is known about the occupational determinants of renal cancer. ${ }^{1}$ Raised risks have been reported among coke oven workers, ${ }^{2}$ laundry and dry cleaning workers, ${ }^{34}$ newspaper pressmen, ${ }^{5}$ and workers handling asbestos ${ }^{6}$ and petroleum, tar, and pitch products. ${ }^{78}$ Although the data were usually not reported separately by site within the kidney, the vast majority of tumours in these studies arose in the renal parenchyma (renal cell cancer). An excess riskof renal pelvis cancer has been reported for leather workers ${ }^{9}$ and a number of workplace exposures associated with bladder cancer. ${ }^{10}$ The Swedish Cancer-Environment Registry (CER), which links essentially complete cancer incidence data for 1960-79 with employment data obtained from the 1960 national census, ${ }^{11}$ provides a unique opportunity to assess separately the occurrence of renal cell cancer (ICD 7th rev 180.0) and renal pelvis cancer (ICD 180.1) by industry and occupation for an entire country. We report here the results from this hypothesis generating investigation, the first to evaluate systematically occupational risks for renal cancer using large scale population based incidence date. The location of the study is of special interest, since Sweden and other Scandinavian countries have the highest rates of renal cancer in the world. ${ }^{1}$

\section{Methods}

A description of the CER and the statistical methods Accepted 6 May 1986 used in calculating the standardised incidence ratios (SIR) have been published before. ${ }^{12}$ SIRs were calculated for all major (one digit) and general (two digit) industrial and occupational codes. For specific (three digit) employment groups only those with 500 or more individuals were evaluated, as there are over 300 industrial and 300 occupational categories at this level of coding. Few raised risks were observed among employed women; hence only the results for men will be presented (except in those instances where female risks may clarify the observed patterns).

\section{Results}

Among Swedish men employed in 1960 , there were 7405 cases of renal cell cancer $\mathbf{9 9 \%}$ microscopically confirmed) and 821 cases of renal pelvis cancer $(98 \%$ microscopically confirmed) during the 19 year follow up. Ninety five per cent of the cases of renal cell cancer were adenocarcinomas and $4 \%$ unspecified epithelial cancers; $80 \%$ of the cases of renal pelvis cancer were transitional cell carcinomas, $5 \%$ squamous cell cancer, and $12 \%$ unspecified epithelial cancers.

For the major divisions of industry and occupation in Sweden (table 1) the highest risks for the renal cell cancer occurred among professional, technical, and related workers (SIR $=1.20, p<0.01)$. There were also significantly raised SIRs for the white collar occupations of administrative workers and sales workers, and for the services industry. By contrast, the highest risks for renal pelvis cancer occurred 
Table 1 Standardised incidence ratios (SIR) for renal cell and renal pelvis cancers by major division of industry and occupation among me

\begin{tabular}{|c|c|c|c|c|c|c|c|c|c|c|c|}
\hline Code & Major industry & $\begin{array}{l}\text { Renal cell } \\
\text { cancer cases }\end{array}$ & SIR† & $\begin{array}{l}\text { Renal pelvis } \\
\text { cancer cases }\end{array}$ & SIR† & Code & Major occupation & $\begin{array}{l}\text { Renal cell } \\
\text { cancer cases }\end{array}$ & SIR† & $\begin{array}{l}\text { Renal pelvis } \\
\text { cancer cases }\end{array}$ & SI磨 \\
\hline$\overline{0}$ & $\begin{array}{l}\text { Farming, forestry, } \\
\text { hunting, and fishing }\end{array}$ & 1287 & $0 \cdot 88^{*}$ & 105 & $0.67^{*}$ & 0 & $\begin{array}{l}\text { Professional, technical, } \\
\text { and related workers }\end{array}$ & 995 & $1 \cdot 20^{*}$ & 106 & \\
\hline 1 & Mining and quarrying & 56 & $0 \cdot 86$ & 8 & $1 \cdot 31$ & 1 & $\begin{array}{l}\text { Administrative, executive, } \\
\text { and managerial } \\
\text { workers }\end{array}$ & 319 & $1 \cdot 14^{* *}$ & 29 & \\
\hline 2 & $\begin{array}{l}\text { Manufacturing I } \\
\text { Manufacturing II }\end{array}$ & $\begin{array}{l}1024 \\
1658\end{array}$ & 1.01 & $\begin{array}{l}119 \\
211\end{array}$ & 1.05 & $\begin{array}{l}2 \\
3\end{array}$ & $\begin{array}{l}\text { Clerical workers } \\
\text { Sales workers }\end{array}$ & $\begin{array}{r}309 \\
581\end{array}$ & $1 \cdot 08$ & $\begin{array}{r}36 \\
64\end{array}$ & \\
\hline 4 & Construction & 983 & 1.02 & 113 & 1.07 & 4 & $\begin{array}{l}\text { Farmers, fishermen, } \\
\text { hunters, and related } \\
\text { workers }\end{array}$ & 1255 & $0.87^{*}$ & 102 & \\
\hline 5 & $\begin{array}{l}\text { Electric, gas, water, } \\
\text { and sanitary services }\end{array}$ & 131 & $1 \cdot 17$ & 13 & 1.07 & 5 & $\begin{array}{l}\text { Miners, quarrymen, } \\
\text { and related workers }\end{array}$ & 50 & 1.04 & 7 & \\
\hline 6 & $\begin{array}{l}\text { Trade, finance, } \\
\text { insurance, real estate }\end{array}$ & 773 & 1.04 & 83 & 1.01 & 6 & $\begin{array}{l}\text { Transport and } \\
\text { communication }\end{array}$ & 532 & 1.00 & 55 & \\
\hline 7 & $\begin{array}{l}\text { Transport and } \\
\text { communication }\end{array}$ & 606 & 1.04 & 71 & $1 \cdot 11$ & 7 & $\begin{array}{l}\text { Craftsmen, production } \\
\text { workers, and labourers }\end{array}$ & 2048 & 1.02 & 240 & \\
\hline 8 & Services & 868 & $1 \cdot 13^{*}$ & 97 & $1 \cdot 14$ & 8 & $\begin{array}{l}\text { Craftsmen, production } \\
\text { workers, and } \\
\text { labourers, NEC }\end{array}$ & 965 & 0.94 & 140 & \\
\hline 9 & $\begin{array}{l}\text { Non-classifiable } \\
\text { services }\end{array}$ & 19 & $0 \cdot 85$ & 1 & $0 \cdot 41$ & 9 & $\begin{array}{l}\text { Services, sport, and } \\
\text { recreation workers }\end{array}$ & 351 & 1.08 & 42 & \\
\hline
\end{tabular}

${ }^{*} \mathrm{p}<0.01 ;{ }^{* *} \mathrm{p}<0.05$.

tAdjusted for age and region.

NEC $=$ Not elsewhere classified.

Table 2 Standardised incidence ratios (SIR) for renal cell and renal pelvis cancers by general (two digit) manufacturing industries and craftsman tradesman occupations among men

\begin{tabular}{|c|c|c|c|c|c|c|c|c|c|c|c|}
\hline Code & General industry & $\begin{array}{l}\text { Renal cell } \\
\text { cancer cases }\end{array}$ & SIR† & $\begin{array}{l}\text { Renal pelvis } \\
\text { cancer cases }\end{array}$ & SIR† & Code & General occupation & $\begin{array}{l}\text { Renal cell } \\
\text { cancer cases }\end{array}$ & SIR† & $\begin{array}{l}\text { Renal pelvis } \\
\text { cancer cases }\end{array}$ & SI $\overrightarrow{8}$ \\
\hline 20 & Food products & 167 & 0.92 & 29 & 1.41 & 70 & $\begin{array}{l}\text { Spinners, weavers, } \\
\text { and knitters }\end{array}$ & 57 & $1 \cdot 24$ & 3 & Ф663 \\
\hline $\begin{array}{l}21 \\
22\end{array}$ & $\begin{array}{l}\text { Tobacco and beverages } \\
\text { Textile }\end{array}$ & $\begin{array}{r}29 \\
100\end{array}$ & $\begin{array}{l}0 \cdot 89 \\
1 \cdot 11\end{array}$ & $\begin{array}{l}4 \\
8\end{array}$ & $\begin{array}{l}1.08 \\
0.84\end{array}$ & $\begin{array}{l}71 \\
72\end{array}$ & $\begin{array}{l}\text { Tailors, cutters, furriers } \\
\text { Shoe and leather workers }\end{array}$ & $\begin{array}{l}45 \\
46\end{array}$ & $\begin{array}{l}0.79 \\
1.06\end{array}$ & $\begin{array}{l}7 \\
5\end{array}$ & 宙i害 \\
\hline 23 & Apparel & 110 & 0.97 & 15 & 1.25 & 73 & $\begin{array}{l}\text { Metal making and } \\
\text { treating workers }\end{array}$ & 137 & 0.96 & 20 & 1.36 \\
\hline 24 & $\begin{array}{l}\text { Lumber and wood } \\
\text { products }\end{array}$ & 215 & 1.04 & 16 & $0 \cdot 70$ & 74 & $\begin{array}{l}\text { Precision instrument } \\
\text { makers }\end{array}$ & 35 & 1.07 & 4 & \\
\hline 25 & Furniture and fixtures & 59 & 0.86 & 8 & 0.94 & 75 & Toolmakers, machinists, & 699 & 1.07 & 95 & 1.3蓉* \\
\hline 26 & $\begin{array}{l}\text { Paper and allied } \\
\text { products }\end{array}$ & 202 & 1.07 & 23 & $1 \cdot 12$ & 76 & $\begin{array}{l}\text { Electricians, electronic } \\
\text { workers }\end{array}$ & 173 & 1.08 & 22 & \\
\hline 27 & $\begin{array}{l}\text { Printing and } \\
\text { publishing }\end{array}$ & 125 & 1.02 & 14 & 1.02 & 77 & Woodworkers & 452 & 1.02 & 37 & $0.7 \frac{5}{0}$ \\
\hline $\begin{array}{l}28 \\
30\end{array}$ & $\begin{array}{l}\text { Leather } \\
\text { Rubber }\end{array}$ & $\begin{array}{l}17 \\
28\end{array}$ & $\begin{array}{l}1 \cdot 15 \\
0.95\end{array}$ & $\begin{array}{l}2 \\
4\end{array}$ & $\begin{array}{l}1 \cdot 23 \\
1 \cdot 10\end{array}$ & $\begin{array}{l}78 \\
79\end{array}$ & $\begin{array}{l}\text { Painters, paperhangers } \\
\text { Bricklayer and } \\
\text { construction } \\
\text { worker, NEC }\end{array}$ & $\begin{array}{l}124 \\
280\end{array}$ & $\begin{array}{l}0.94 \\
0.90\end{array}$ & $\begin{array}{l}10 \\
37\end{array}$ & $\begin{array}{r}0.68 \\
1.080 \\
\frac{8}{3}\end{array}$ \\
\hline 31 & Chemical & 92 & 1.07 & 7 & 0.74 & 80 & Graphical worker & 55 & $0 \cdot 84$ & 11 & $1.5 \%$ \\
\hline 32 & $\begin{array}{l}\text { Coal and petroleum } \\
\text { refining }\end{array}$ & 12 & 0.77 & 2 & $1 \cdot 16$ & 81 & $\begin{array}{l}\text { Potters, kilnmen, and } \\
\text { glass workers }\end{array}$ & 24 & 0.73 & 8 & 2.15. \\
\hline 33 & Stone, clay, glass & 113 & $0 \cdot 86$ & 16 & $1 \cdot 10$ & 82 & Food industry worker's & 108 & 0.95 & 16 & 1.25 \\
\hline 34 & $\begin{array}{l}\text { Fabricated metal } \\
\text { products }\end{array}$ & 398 & 0.99 & 49 & $1 \cdot 17$ & 83 & $\begin{array}{l}\text { Chemical and cellulose } \\
\text { workers }\end{array}$ & 107 & 0.96 & 14 & $\begin{array}{r}1 \cdot 15 \\
0\end{array}$ \\
\hline 35 & $\begin{array}{l}\text { Machinery and } \\
\text { electronics }\end{array}$ & 611 & $1 \cdot 14^{*}$ & 85 & $1 \cdot 42^{*}$ & 84 & Tobacco workers & $\mathbf{0}$ & - & $\mathbf{0}$ & \\
\hline 36 & $\begin{array}{c}\text { Transportation } \\
\text { equipment }\end{array}$ & 335 & $1 \cdot 10$ & 34 & 0.98 & 85 & $\begin{array}{l}\text { Craftsmen \& production } \\
\text { process workers }\end{array}$ & 77 & 0.95 & 10 & 1.0星. \\
\hline 37 & $\begin{array}{l}\text { Miscellaneous } \\
\text { manufacturing }\end{array}$ & 67 & $1 \cdot 19$ & 14 & $2 \cdot 15^{* *}$ & 86 & Labourers, NEC & 191 & 0.83 & 25 & 0.9 ర్రి \\
\hline 39 & Manufacturing, NEC & 2 & 0.76 & 0 & - & 87 & $\begin{array}{l}\text { Stationary engine and } \\
\text { equipment } \\
\text { operators }\end{array}$ & 170 & $1 \cdot 15$ & 17 & $\begin{array}{l}1.0 \mathbb{O} \\
\text { N } \\
\omega\end{array}$ \\
\hline 40 & $\begin{array}{c}\text { Home building } \\
\text { construction }\end{array}$ & 508 & 1.02 & 52 & 0.95 & 88 & $\begin{array}{l}\text { Stationary engine and } \\
\text { equipment operator }\end{array}$ & 233 & 0.93 & 39 & $1 \cdot 38$ \\
\hline 41 & Other construction & 475 & 1.02 & 61 & $1 \cdot 20$ & & & & & & $\stackrel{0}{2}$ \\
\hline \multicolumn{11}{|c|}{$\begin{array}{l}{ }^{*} \mathrm{p}<0.01 ;{ }^{* *} \mathrm{p}<0.05 \\
+ \text { tAdjusted for age and region. } \\
\text { NEC }=\text { Not elsewhere classified. }\end{array}$} & 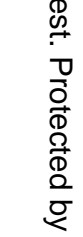 \\
\hline
\end{tabular}


Table 3 Statistically significant $(p<0.05)$ standardised incidence ratios $(S I R)$ for renal cell and renal pelvis cancers for specific (three digit) industries and occupation among men

\begin{tabular}{|c|c|c|c|c|c|c|c|}
\hline Code & Specific industry & Cases & SIRT & Code & Specific occupation & Cases & $S I R+$ \\
\hline 015 & Veterinary medicine & 7 & \multicolumn{2}{|c|}{$2.59 \begin{array}{c}\text { Renal cell cancer } \\
006\end{array}$} & $\begin{array}{l}\text { Engineers and technicians in } \\
\text { other technical fields }\end{array}$ & 80 & $1 \cdot 28$ \\
\hline $\begin{array}{l}220 \\
350 \\
352 \\
362 \\
412 \\
702 \\
804\end{array}$ & $\begin{array}{l}\text { Wool industry } \\
\text { Machine industry } \\
\text { Other electronics industry } \\
\text { Railroad and trolley works } \\
\text { Building sheetmetal construction } \\
\text { Automobile transportation } \\
\text { Police work }\end{array}$ & $\begin{array}{r}33 \\
435 \\
165 \\
48 \\
20 \\
65 \\
45\end{array}$ & $\begin{array}{l}1.61 \\
1.13 \\
1.20 \\
1.45 \\
1.79 \\
1.33 \\
1.45\end{array}$ & $\begin{array}{l}031 \\
054 \\
085 \\
111 \\
294 \\
313 \\
755 \\
902\end{array}$ & $\begin{array}{l}\text { Physicians } \\
\text { Teachers of practical subjects } \\
\text { Journalists and editors } \\
\text { Business executives } \\
\text { Dispatchers and shipping agents } \\
\text { Advertisers } \\
\text { Welders and metal cutters } \\
\text { Police }\end{array}$ & $\begin{array}{r}33 \\
21 \\
34 \\
201 \\
28 \\
13 \\
71 \\
41\end{array}$ & $\begin{array}{l}1.48 \\
1.71 \\
1.88^{*} \\
1.23^{*} \\
1.99^{*} \\
1.98 \\
1.31 \\
1.52\end{array}$ \\
\hline $\begin{array}{l}820 \\
851\end{array}$ & $\begin{array}{l}\text { Health care } \\
\text { Fine arts and music } \\
\text { composition }\end{array}$ & $\begin{array}{r}103 \\
20\end{array}$ & $\begin{array}{l}1 \cdot 28 \\
1 \cdot 75\end{array}$ & 981 & Military service & 52 & 1.35 \\
\hline 853 & Theatres & 11 & $2 \cdot 14$ & & & & \\
\hline 102 & Other ore mining & 4 & $4 \cdot 49^{R}$ & $\begin{array}{l}\text { pelvis cancer } \\
005\end{array}$ & $\begin{array}{l}\text { Engineers and technicians in } \\
\text { mining and metallurgy }\end{array}$ & 6 & $3 \cdot 29$ \\
\hline $\begin{array}{l}350 \\
370\end{array}$ & $\begin{array}{l}\text { Machine industry } \\
\text { Scientific and surgical } \\
\text { instrument construction }\end{array}$ & $\begin{array}{r}70 \\
6\end{array}$ & $\begin{array}{l}1 \cdot 60^{*} \\
5 \cdot 18^{*}\end{array}$ & $\begin{array}{l}071 \\
331\end{array}$ & $\begin{array}{l}\text { Judges } \\
\text { Wholesale buyers }\end{array}$ & $\begin{array}{r}5 \\
19\end{array}$ & $\begin{array}{l}9 \cdot 16^{*} \\
1.91\end{array}$ \\
\hline $\begin{array}{l}413 \\
802 \\
853\end{array}$ & $\begin{array}{l}\text { Plumbing installation } \\
\text { Legal services } \\
\text { Theatres }\end{array}$ & $\begin{array}{r}18 \\
7 \\
3\end{array}$ & $\begin{array}{l}2 \cdot 37^{*} \\
4 \cdot 67^{*} \\
5 \cdot 23\end{array}$ & $\begin{array}{l}750 \\
754\end{array}$ & $\begin{array}{l}\text { Machinists and toolmakers } \\
\text { Plumbers }\end{array}$ & $\begin{array}{l}31 \\
15\end{array}$ & $\begin{array}{l}1 \cdot 52 \\
2 \cdot 17\end{array}$ \\
\hline
\end{tabular}

$* \mathrm{p}<0.01$

†Adjusted for age and region.

among blue collar occupations (craftsmen, production workers, and labourers, SIR $=1 \cdot 22, \mathrm{p}<$ 0.05 ) and for mining and manufacturing industries, although non-significantly raised SIRs were seen among professional and service workers. For both renal cell and renal pelvis cancers, significantly decreased SIRs were found among farmers, forestry, fishing, and related workers.

Because previous clues to occupational factors centered on jobs and exposures in manufacturing, SIRs were calculated for all general (two digit) manufacturing industries and craftsman tradesman occupations (table 2). Significantly raised risks for both cancers were seen for men in the machinery and electronics industry. SIRs exceeding 1.0 were more often observed for renal pelvis cancer, however, with the excesses being significant among those employed in miscellaneous manufacturing, and as toolmakers, machinists, plumbers, and welders.

Table 3 (top panel) shows in which specific (three digit) industries and occupations there are significantly raised $(p<0.05)$ SIRs associated with renal cell cancer. Several health related professions and the health care industry appear to have a raised risk for renal cell cancer. A significantly high SIR was found for physicians and the risk for dentists was also raised (SIR $=1.62 ; 20$ cases) and of borderline statistical significance $(p=0.06)$. For the general (two digit) occupation of medical professionals, which combines physicians and dentists, the SIR was increased and highly significant (SIR $=1.53 ; 53$ cases; $p<0.01$ ). Most of the other occupations with raised SIRs were white collar professions. The bottom panel of table 3 shows specific industries and occupations with significantly raised SIRs for renal pelvis cancer. SIRs for this cancer were generally higher than those for renal cell cancer, although based on many fewer observations.

\section{Discussion}

This hypothesis generating study showed several statistically significant occupational associations for cancers of the renal parenchyma and renal pelvis. In general, the occupational patterns of renal cell cancer differed from those of renal pelvis cancer. The SIRs for renal cell cancer tended to be high among white collar workers whereas the SIRs for renal pelvis cancer were generally higher among blue collar employees.

The increased risk of renal cell cancer among health professionals (physicians, dentists, and veterinary surgeons) is consistent with findings from a recent occupational mortality analysis in the United States. ${ }^{13}$ It is not clear whether this association reflects occupational exposures or, perhaps more likely, lifestyle risk factors for this cancer, including smoking habits, body weight, meat and fat consumption, analgesic use, or diagnostic surveillance. $^{81415}$ Tobacco smoking appears an unlikely 
explanation, however, since smoking rates for Swedish health professionals in 1963 were comparable with those for the general population (J Carstensen, personal communication). The high rates observed among welders, military personnel, journalists and editors, and dispatchers and shipping agents, have been reported in previous occupational surveys. ${ }^{16-18}$

Some occupational categories have been previously linked to renal cell cancer but did not emerge as high risk groups in the present survey. For example, the raised risk observed among coke oven workers in the United States ${ }^{2}$ was not detected in the categories of iron and steel making (SIR $=0.98 ; 145$ cases) or hearth and furnace workers (SIR $=0.94 ; 7$ cases), although no specific code exists for coke oven workers. The SIRs for the laundry and dry cleaning industry were 0.99 (18 cases) among men and 0.86 (25 cases) among women, indicating no increased risk such as has been observed in the United States. ${ }^{34}$ Unlike previous reports, ${ }^{5-7}$ we found no excess risk among printing or graphical workers (SIR $=0.83 ; 47$ cases), insulation workers (SIR $=0.98 ; 2$ cases), or among workers in petroleum refineries (SIR $=0.92 ; 8$ cases) or gasoline stations (SIR $=0.59 ; 9$ cases).

Our earlier communication on kidney cancer reported excesses of renal cell cancer among tanners and of renal pelvis cancer among shoe factory workers between 1961 and $1973 .{ }^{19}$ With the longer period of follow up, these associations persisted but were no longer statistically significant among tanners (SIR = $1.56 ; 9$ cases) or shoe factory workers (SIR $=2.68 ; 4$ cases). The inclusion of women in the latter category, however, did result in a significant association (SIR $=2.82 ; 6$ cases). This appears consistent with a casecontrol study indicating that leather workers are prone to renal pelvis cancer. ${ }^{9}$ The significantly raised SIRs among machinists and toolmakers, plumbers, and workers in the machine industry are new aetiological leads, although machinists and plumbers are reported to be at increased risk of bladder cancer, ${ }^{20}$ a tumour with risk factors resembling those of renal pelvis cancer. ${ }^{1}$

Although this record linkage study may provide occupational clues to the origins of renal cancer, the CER has limitations that preclude making causal inferences. ${ }^{12}$ For example, there is no information on the duration of employment or on non-occupational factors that may influence the risk of renal cancer. Since the effect of cigarette smoking appears greater for renal pelvis cancer ${ }^{10}$ than renal cell cancer, ${ }^{8}$ occupational differences in smoking prevalence would more likely influence the associations with renal pelvis cancer. The 1963 survey of smoking habits in Sweden found similar proportions of smokers in both blue collar (exclusive of agricultural jobs) and white collar workers. ${ }^{21}$ The prevalence of smok- ing, however, was higher among individuals in the specific occupations of toolmakers and machinists $\frac{3}{\Phi}$ (59\% smokers) and plumbers (57\% smokers) than among the general male population $(46 \%$ smokers $)(\mathrm{J} \underset{\overrightarrow{\mathrm{F}}}{\overrightarrow{\mathrm{D}}}$ Carstensen, personal communication). Smoking may thus partly account for the excess risks associated with these job categories. Smoking may also con- $\frac{\bar{c}}{\frac{D}{D}}$ tribute to the deficit of both cancers (most pro- $\frac{\Gamma}{\sigma}$ nounced for renal pelvis cancer) among farmers, since $\supseteq$ as a group, farmers smoke less. ${ }^{21}$ The multiple comparisons made in this study also affect the inter- $\vec{\circ}$ pretation of the findings, since there were few a priori leads and a large number of employment categories $\vec{\omega}$ were reviewed. It is difficult to know, therefore, $\frac{\circ}{\circ}$ whether to place much credibility in statistically significant associations for specific (three digit) industries or occupations when almost 800 such categories + were studied for the two cancers, and many associ- $?$ ations are expected on the basis of chance alone. It is $\vec{\omega}$ noteworthy, however, that several findings of our sur-o vey are consistent with previously reported associations for renal cancer.

Requests for reprints to: $\mathrm{Dr}$ J K McLaughlin, Biostatistics Branch, National Cancer Institute, Landow Building, Room 3C16, Bethesda, Maryland 20892.

\section{References}

1 McLaughlin JK, Schuman LM. Epidemiology of renal cell carcinoma. In: Lilienfeld AM, ed. Reviews in cancer epidemiology. Vol 2. New York: Elsevier, 1983:170-210.

2 Redmond CK, Ciocco A, Lloyd W, Ruch HW. Long-term mor- $\overline{\bar{O}}$ tality study of steelworkers. VI. Mortality from malignant neoplasms among coke oven workers. J Occup Med 1972;14:621-9.

3 Katz RM, Jowett D. Female laundry and dry cleaning workers in Wisconsin: a mortality analysis. Am $J$ Public Health $\bigcirc$ 1981;71:305-7.

4 Duh RW, Asal NR. Mortality among laundry and dry cleaning workers in Oklahoma. Am J Public Health 1984;74:1278-80.

5 Paganini-Hill A, Glazer E, Henderson BE, Ross RK. Causespecific mortality among newspaper web pressmen. J Occup Med 1980;22:542-4.

6 Selikoff IJ, Hammond EC, Seidman M. Mortality experience of insulation workers in the United States and Canada, 1943-76. 음 Ann NY Acad Sci 1979;330:91-116.

7 Savitz DA, Moure R. Cancer risk among oil refinery workers: a음 review of epidemiologic studies. J Occup Med 1984;26:662-70.

8 McLaughlin JK, Mandel JS, Blot WJ, Schuman LM, Mehl ES, N Fraumeni JF, Jr. A population-based case-control study of renal cell carcinoma. JNCI 1984;72:275-84.

9 Schmauz R, Cole P. Epidemiology of cancer of the renal pelvis and ureter. JNCI 1974;52:1431-4.

10 McLaughlin JK, Blot WJ, Mandel JS, Schuman LM, Mehl ES, Fraumeni JF, Jr. Etiology of cancer of the renal pelvis. JNCKe 1983;71:287-91.

11 Wiklund K, Einhorn J, Wennstrom G, Rappaport E. A Swedish $\mathscr{S}$ cancer environment registry available for research. Scand $J_{T}^{-}$ Work Environ Health 1981;7:64-7. 
12 Malker HSR, McLaughlin JK, Malker BK, et al. Biliary tract cancer and occupation in Sweden. $\mathrm{Br} J$ Ind Med 1986;43:257-62.

13 Dubrow R, Wegman DH. Occupational characteristics of white male cancer victims in Massachusetts 1971-3. Cincinnati: Department of Health and Human Services, National Institute of Occupational Safety and Health, 1984.

14 Wynder EL, Mabuchi K, Whitmore WF, Jr. Epidemiology of adenocarcinoma of the kidney. JNCI 1974;53:1619-34.

15 Curtis RE, Boice JD, Jr, Kleinerman RA, Flannery JT, Fraumeni JF, Jr. Summary: multiple primary cancers in Connecticut, 1935-82. Natl Cancer Inst Monogr 1985;68:219-42.

16 Milham S. Occupational mortality in Washington state, 1950-79. Cincinnati: Department of Health and Human Services, National Institute of Occupational Safety and Health, 1983.
17 Dubrow R, Wegman DH. Setting priorities for occupational cancer research and control: synthesis of the results of occupational disease surveillance studies. JNCI 1983;71:1123-42.

18 Petersen GR, Milham S. Occuptional mortality in the state of California 1959-61. Cincinnati: Department of Health, Education, and Welfare, National Institute of Occupational Safety and Health, 1980.

19 Malker HSR, Malker BK, McLaughlin JK, Blot WJ. Kidney cancer among leather workers. Lancet 1984;i:56.

20 Matanoski GM, Elliott EA. Bladder cancer epidemiology. Epidemiol Rev 1981;3:203-29.

21 Survey Research Institute. The cigarette-a study of personality and motives. Stockholm: National Control Bureau of Statistics, 1972. (English summary only.) 